\title{
Raising Awareness of Indonesia's Climate Change Mitigation by Social Media Campaign
}

Juan Malik Frederick Turpyn ${ }^{1}$ and Anggaraksa Adwitiya ${ }^{2}$

1, 2 Universitas Al-Azhar, Jakarta, Indonesia

\begin{abstract}
Climate change is a big concern that must be realized because it has become a problem in various sectors both at the international, regional, national and local levels. The occurrence of climate change will certainly also affect the occurrence of extreme weather and disasters - disasters that are not wanted by the public at large. However, the level of public awareness of the bad climate change is still fairly low due to the lack of knowledge about climate change. People can play a role in dealing with climate change, and be actors in mitigating these changes. The use of public communication can increase public awareness and participation in adaptation and mitigation actions on climate change can be realized in many ways, one of which is campaigning to the public. The purpose of this research is to find out how the implementation of social media campaigns in raising awareness of Indonesia's climate change mitigation in the future. The research method that will be used is qualitative with data collection techniques used is Focus Group Discussion, document studies and observations on the intended social media accounts. Researchers did simple research by creating social media accounts to conduct campaigns on the SDGs' points on climate change. The result of this research is the implementation of social media campaigns in raising awareness of Climate Change Mitigation in Indonesia raises various positive aspects ranging from changes in people's lifestyles and presenting good awareness.
\end{abstract}

Keywords: Awareness; Climate; Change; Mitigation; social media; Campaign

KEYWORDS

Awareness;

Climate;

Change;

Mitigation;

social media;

Campaign

\section{INTRODUCTION}

The issue of climate change itself has become a major concern from various sectors both at the international, regional, national, and even local levels. Various events related to erratic climatic conditions such as floods, droughts, landslides with increasing intensity have caused many fatalities, economic losses, and ecological damage. These conditions need to be addressed by strengthening regional-level actions that can contribute to mitigation efforts in reducing emissions as well as adaptation efforts to increase the capacity of all parties in dealing with the impacts of climate change. The occurrence of climate change will certainly also affect the occurrence of extreme weather and disasters - disasters that are not wanted by the public at large. In a matter of years, the Earth's temperature has warmed by 1 degree Fahrenheit and will probably continue to rise by 
more than 4-6 degrees in the future. These conditions will result in rising global temperatures and changes in weather pattern.

It is also important to know that people's knowledge of climate change is still minimal. A number of experts in the country also voiced that public awareness about climate change is still low. In fact, knowledge of the impacts of climate change is important so that people can adapt and mitigate from simple things (Media Indonesia, 2018). Mitigation can be done for example by processing waste, processing livestock manure, the use of solar cells for electrical energy. The capacity of people to adapt to climate change is critical to adaptive. If not addressed immediately then this climate change situation can be even more dangerous. In fact, people can play a role in dealing with climate change, and be actors in mitigating these changes. With public communication conducted by the government, in the future there will be a shared understanding of the impacts of climate change so that the level of awareness and education can be conveyed clearly to the public.

Figure 1. Sustainable Development Goals

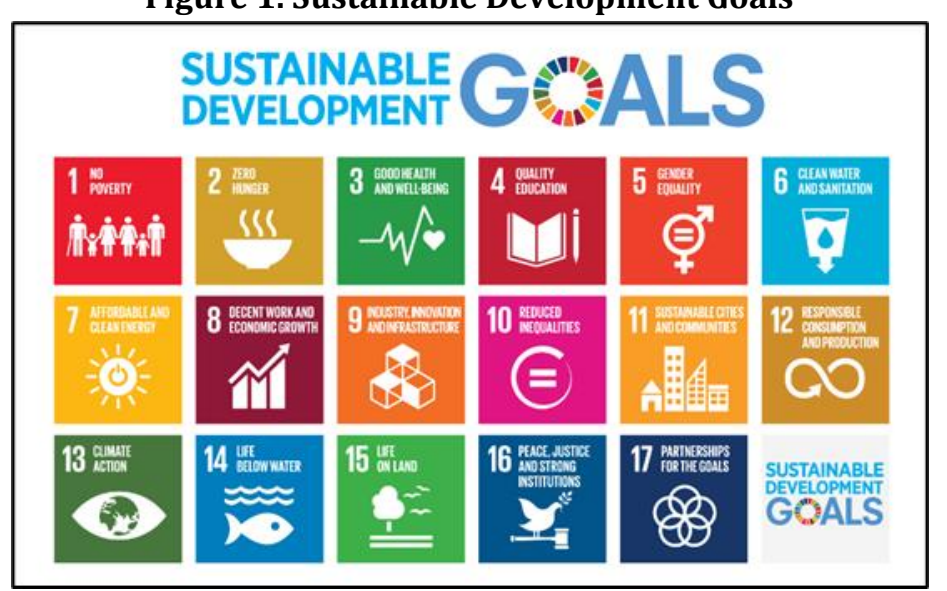

Source: SDG 2030 Indonesia (n.d.)

The implementation of education and awareness of climate change is certainly in line with the points of the Sustainable Development Goals on Handling Climate Change. In this point also corresponds to target number 3 on climate change about: "Improving education, awareness growth, and human and institutional capacity related to mitigation, adaptation, impact reduction and early warning of climate change" The real implementation of this education and awareness improvement is closely related to the Sustainable Development Goals (SDGs). So, it is important to prepare the appropriate media or containers in preparation for the realization of this Sustainable Development Goals. The use of public communication as an awareness and public participation in climate change adaptation and mitigation actions can be realized in many ways, including the equalization of information and also campaigns to the public. The public can find out what the purpose of this mitigation is with the implementation of the campaign. This campaign comes as a way that can connect structured communication between institutions and the public. 
The message that the agency wants to convey to the target it is aiming for can be in a variety of ways, ranging from information disseminated by the mass media to the use of persuasive campaigns to a wide audience. The process of conveying information on climate change can give rise to various educational views about the SDGs and climate, if in the end the relevant institutions want to use the campaign as a medium in conveying their message, it is necessary to pay attention to the aspects that are implemented in the future. So that the hopes and objectives of the message can be conveyed as best as possible.

The message of the SDG's campaign will become more maximal with the review of theories - media theories that include the understanding and type of media used in conveying the information. The media used in the implementation of this campaign can be various, can be with mass media or social media. The existence of social media is a means for anyone to be used to disseminate information in the form of text, images, audio, and video with many parties either between companies to the public or vice versa (Kotler, 2012). A lot of social media to choose from when going on a campaign aimed at the public, the main social media that is suitable to carry out this is Instagram. Instagram application becomes part of social media that focuses on one's activities or activities to be disseminated to the public, so that the public can know the activities of a person or company from Instagram that he uses. Instagram can be used to post images or photos. Unique and good features make Instagram as a social media that can store a large number of photos. There are also many activities that can be used in displaying the resulting image so that it becomes better than the previous image.

Using social media application Instagram can realize the delivery of messages or information that is appropriate to the public. As part of the development of the industrial revolution, the use of social media is also considered appropriate or appropriate in conveying the desired message. The rapid development of the media campaign can also have a relevant impact on the aoa expected by the relevant institutions. Based on the background introduction, the researchers focused on "how to implement social media campaigns in raising awareness of Indonesia's climate change mitigation" so that later research objectives will be obtained to find out how to implement social media campaigns in raising awareness of Indonesia's climate change mitigation in the future.

The campaign is a synonymous with delivering structured messages to the public. Venus in her book explains that the campaign can be said to be a planning of a series of communication actions with the aim of creating a certain effect for the wider community and carried out on an ongoing basis at a set time. The purpose of social campaigns is usually to raise public awareness of the ongoing social problems. Therefore, this social campaign is termed as the sale of ideas to the community. Examples of educational campaigns are health care, anti-smoking, littering in place, and more (Venus, 2012). 
The use of new media as a campaign flow certainly makes the company more flexible in finding information and how to disseminate it by providing audio, visual and text selection of publications as ways that can be used / chosen by internet users. While on social media they can also encourage the involvement of various parties in building a certain level on aspects of interactivity and participation among fellow users in the media (Valentini \& Kruckeberg, 2011). Campaign activities have several objectives, but if you want to be associated with the educational element there are several objectives of the campaign itself. Therefore, the purpose of the educational campaign is (Ruslan, 2006, p. 26-28): (1) public awareness, campaign aims to create public awareness of a social interest such as education and health; (2) offer information, provide clear and complete and in-depth information about a particular campaign program to the public so that the public cares. Information is offered through brochures, magazines, guidebooks on the concepts that are in circulation; and (3) public education, public relations campaign practitioners should aim at the public emotionally who remain ethical and reasonable in expressing their opinions in pedagogic methods, supported by complete campaign materials about the information and objectives of the program. Campaign activities are persuasive. Similarly, to the purpose of the implementation of educational campaigns, it is necessary to remember that this education is very closely related to the purpose of the message to be obtained.

Social media is the renewable media of digital media and is developing in the era of industrial revolution 4.0, Van Dijk said in his book that social media is a media platform that focuses on the existence of users who facilitate them in activities and collaboration. Therefore, social media can be seen as an online medium (facilitator) that strengthens the relationship between users as well as a social bond. Social media or also known as social networks is part of the new media. It is clear that interactive content in new media is very high. Social media, quoted from a number of sources is defined as an online medium, with its users being able to easily participate, share, and create content including media, social networks, discussions, context and the online world. Web, social networking and publicity are the most common forms of social media used by people around the world (Narsullah, 2015, p. 36-38).

Sometimes social media is also part of the debate, finding people who can be good friends, finding a partner and building a community. From this it is known that the functions of social media implemented later consist of (Wicaksono, 2013): (1) social interaction, in the world of communication, social media is useful as a means to build relationships or networking. Even social media helps individuals or companies to communicate remotely because of the wide reach of this medium. Social media also makes it easier for individuals to interact wherever we are; (2) information media, individuals or companies can upload the latest news on cyberspace to help the public in obtaining a lot of information. Not only news, other information can also be a source of knowledge; and (3) exploring creativity, various forms of social media that exist can be used by the public can hone or explore 
creativity and express individuals. This can be done by conveying various experiences or great ideas from yourself.

One of the efforts that can be done by the company in introducing and improving its existence in the community is through awareness. Awareness is an ability that comes to the public's mind when they think about a particular thing and how easily it appears (Hasbun \& Endang, 2016). There is another sense to say that this consciousness is an individual's ability to recognize, recall a thing from as part of a certain categorization (Aaeker, 1997, p. 61-62). Planting and creating a consumer's memory of a message from the company or about the products or services it produces, will make someone more trusting and arouse their passion to carry out or use the content of the message. The sharper the use of messages from the company in one's mind, the greater the potential of the message or information of the company is implemented by the public at large. To meet these goals, there needs to be sustainable approaches to the community as an effort to identify companies so that consistency is embedded in their minds. Awareness comes as a form of representation of one's concern for something. From this can appear absolute things that so encourage the main functional aspects as a union between thoughts and behaviors in the future.

Climate change mitigation is an effort to reduce the risk of improvement or changes that occur in the environmental situation of life on earth. Such mitigations have been tried from both governments and environmental groups. This step was taken as a form of tangible manifestation of the current condition of the earth (Cahyo, 2018). According to Prof. Karnawati climate change is a long-term change of the distribution of weather patterns statistically over a period of time ranging from decades to millions of years. It can be interpreted as a change in the average weather condition or a change in the distribution of average weather events. Climate change can occur locally, limited to specific regions, or can occur throughout the earth's surface region. The change is characterized by at least four things, firstly due to changes / increases in temperature globally, secondly the increase in sea level height, the third the more frequent occurrence of extreme weather conditions and others, and the fourth there is a change in rainfall patterns.

Climate change is currently characterized by increasing frequency of hydrometeorological disaster events, including reduced water availability reserves and or even the over-discharge of water at other times, as well as forest and land fires. These hydrometeorological disasters will potentially increase based on future climate change projections, and may affect the resilience of water, food, and energy resources. The importance of taking appropriate steps so that these changes can be overcome as early as possible (UGM, 2020). 


\section{METHOD}

This research will use qualitative approach, this approach can generally be used for research on people's lives, history, behavior, organizational functionalization, activities, social, and others. One of the reasons for using qualitative approaches is the experience of researchers where this method can be used to find and understand what is hidden behind a phenomenon that is sometimes difficult to understand satisfactorily (Creswell, 1998, p. 28). Qualitative research is one of the research procedures that produces descriptive data in the form of speech or writing and behavior of the observed people, this study aims to gain a general understanding of social reality from the perspective of participants. Qualitative research is also referred to as interpretive research or naturalistic research (Bogdan, 1992, p. 21-22). Because using qualitative approach, the priority later is to get quality with the formulation of the problem that has been submitted. So that the purpose of the research can also be achieved.

The data collection techniques used later are literature finding, FGD, document study and observation on the intended social media accounts. FGD itself can be said as a way to collect systematic data and information about a particular problem through group discussions. The term FGD is actually a directed group discussion and is basically an interview conducted in a group (Sugiyono, 2009, p. 329).

\section{RESULT AND DISCUSSION}

Campaigns that are later addressed to the public should be prepared as persuasively and communicatively as possible. With regard to the condition of the Sustainable Development Goals, the realization of the campaign becomes a series of organized communication activities with the aim of creating an impact on the importance of sustainable goals to the majority of target audiences in a certain period of time. The implementation of a campaign is inseparable from the communicative elements and management of content and messages Communication about one of SDG's points can be interpreted as a medium that has the purpose of changing or influencing the public (Devito, 2013, p. 62). So, act as expected by the communicators in this case the institution on the importance of maintaining the SDG's as well as climate change.

Associating with the current digital situation, the implementation of the appropriate campaign is to use digital media or social media because both media are identical to the wider audience and millennials. This campaign is expected to change views, opinions, mindsets and behavior changes regarding the purpose of SDG's message. In what is meant is climate change in question. It is important to know together that messages containing the purpose of this communicator should be reviewed a number of ideas, visualizations, and presentations of the content to be delivered. What's later on - this content still stays on the same track without interfering with the implementation of the campaign itself. 
Judging from the theoretical foundation of media ecology initiated by McLuhan, it should be noted that society relies heavily on technology that uses media and that a society's social order is based on the ability to deal with such technology. This media can generally be said as digital media and social media and can directly convey its message to the intended public (Littlejohn \& Foss, 2011). This theory is identical to the real implementation of digital campaigns that will be realized to the public, this is because this study focuses the media and sees it as an environment where the message will change. Campaigns and social media can have a tremendous impact and can later interpret perceptions - perceptions needed in raising public awareness and curiosity. The implementation of this campaign on social media will give the interpretation that the media is always present near them, the media also transform the desired needs so that it will have an impact on life as well.

In its implementation, researchers have conducted simple research, observations and FGD on digital media. Even researchers also created a social media account that can carry out campaigns on the SDGs' points of climate change that can later be consistently implemented. In this case educational content will also be implemented with two content, namely informative and entertainment content.

Digital campaigns will be educational content themed on climate change can be in the form of videos or in the form of images. In addition, the content can also be packed in the form of games or quizzes to make it more interesting, so there is educational content + quiz or games. For this digital campaign we make use of Instagram social media platform which has a very high impression in the community. Content has been uploaded in the form of feeds and stories. If it's a video, we've uploaded it on IGTV.

Picture 2. Example Social Media Campaign

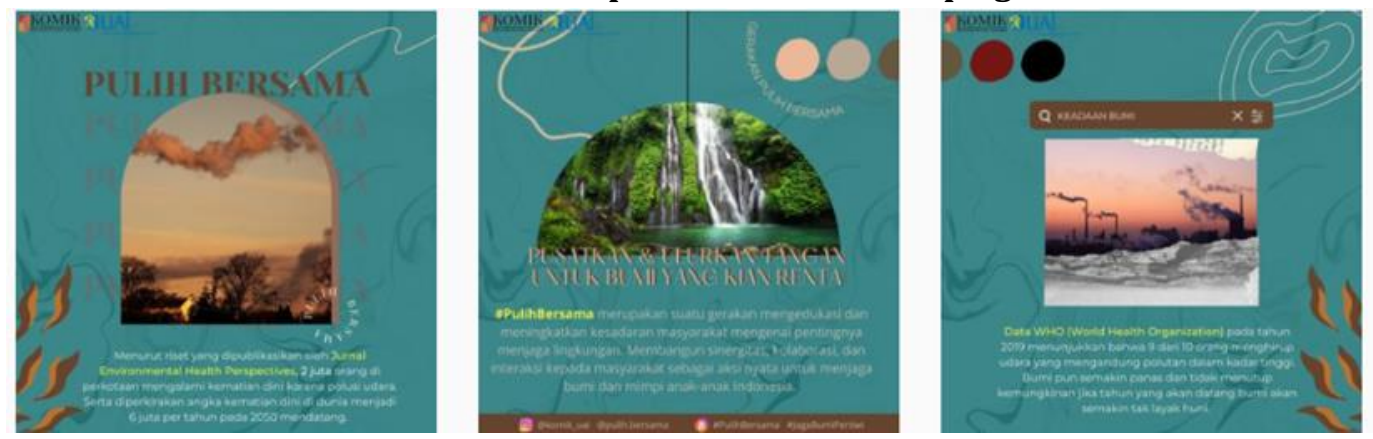

Source: Pulih Bersama Campaign (PulihBersama, 2021)

From the educational content can be seen that the implementation of this digital campaign targets the public to be aware of this climate change situation. Based on an algorithm from Instagram that allows content to enter the explore or a wide part of this social media makes the content visible to the public. In addition, participants of the climate change campaign are also asked to contribute to raise this content in their 
respective accounts to maximize engagement or social media activity so that the context of information can be conveyed to the public.

Picture 3. Example Social Media Campaign
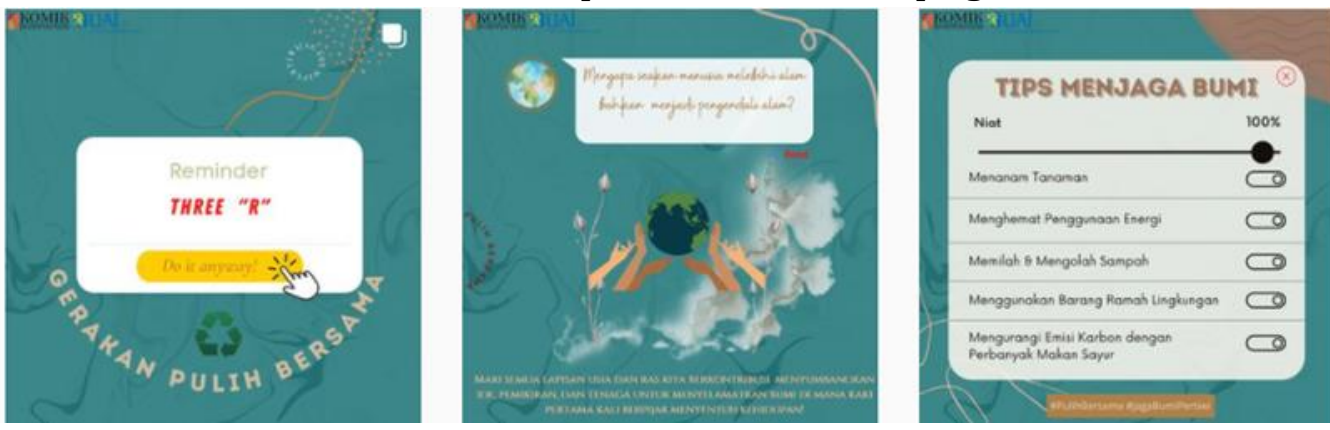

Source: Pulih Bersama Campaign (PulihBersama, 2021)

Based on the content created by the implementers of this campaign, it can circle the message that is serious or rigid only. This attractive content will bring the essence that it is not just about entertainment, but provides a light understanding of climate change. The design and loaded messages are packaged lightly so that the public can broadly interpret as clear as possible. So, the intended message does not seem good - grandiose or excessive because everything is loaded as systematically as possible. The difference with previous media campaigns refers to the emphasis of certain elements, if in the past social media communication used focused on one-way communication only. The campaign will now load bidirectionally, giving rise to novelty and positive interactions. This implementation also presents aspects of volunteers were improving communication and objectives regarding the information in question.

The most important step in the implementation of the campaign and realizing awareness in the community is to know who is the target audience of the campaign and how they respond to the message it receives. Because this aspect makes the main factor that must be considered in the implementation of the climate change campaign. Similarly, after the implementation of the campaign can present a new mindset and behavior of target groups so as to raise awareness of the campaign carried out. Each individual can also show their results, both in the form of cognitive aspects and diverse behaviors. They can understand and realize the importance in protecting the environment. After the implementation of the campaign was also found that various results and responses appeared to individuals because of the use and awareness of the importance of the implementation of Sustainable Development Goals and the importance of climate change mitigation.

Quality change-based campaigns are a form of communication action aimed at changing mindsets, behaviors including building public awareness. So that the goal of quality change regarding climate can be implemented as soon as possible. There is a group or target audience that accepts ideas and campaign results easily, but there are certain groups that are difficult to even reject ideas and ideas about the campaign. This goes back 
to the process of implementing social media campaigns and the environment. By using the technology of the industrial revolution, any message including the SDG's goals can be easily conveyed as long as the communication process is clear.

How the implementation can be realized clearly certainly through various stages that are structured and systematic, first with the design of innovative social media campaigns \&communicative, which then continues along with the preparation of content and messages can move later implementation on the day of execution is also a crucial stage that must be considered. The last stage of evaluation became the determinant of the success of the campaign, in this climate change mitigation campaign went well and made the community aware. This is evident from changes in people's lifestyles to the realization of their consciousness that leads in a positive direction. In the interactive content created by the organizing committee of this campaign activity, to be able to determine whether the implementation can already provide insights to the participants of this campaign. Interactive content comes as a mix of educational stages consisting of knowledge about climate change mitigation or suggestions for this campaign in the future so as to implement it using question and answer as well as some games in the form of bingo.

So that with the existence, interactive content can lead to active communication between the implementing party of campaign activities and campaign participants. This content is created in Instastory on Instagram, so that the content is more easily spread to the wider environment by re-posting the Instastory that has been created by the committee or in other sense, participants re-upload the content in each participant's account.

\section{CONCLUSION}

Based on the research and ideas, it was concluded that the implementation of social media campaigns in raising awareness of Indonesia's climate change mitigation raises various positive aspects ranging from changes in people's lifestyles and presents good awareness. Keep in mind that there is also a group or target audience that accepts ideas and campaign results easily, but there are certain groups that are difficult to even reject ideas and ideas about the campaign itself. This goes back to the process of implementing its own social media campaign. The implementation of this campaign also leads to the Theory of Media Ecology which is identical to the real implementation of digital campaigns to the public, this is because this study focuses the media and sees it as an environment where the message will change and needs to be adjusted to the intended communion in order for awareness to increase. 


\section{REFERENCES}

Aaeker, D. A. (1997). Manajemen Ekuitas Merek (A. Ananda, Trans.). Mitra Utama. (Original work published ca. 1991).

Bogdan, R. C. \& S. K. Biklen. (1992). Qualitative Research for Education: An Introduction to Theory and Methods. Allyn \& Bacon.

Creswell, J. W. (1998). Qualitative Inquiry and Research Design, Choosing Among Five Traditions. Sage Publication

Hasbun, B. \& Ruswanty, E. (2016). Komperasi Antara Kelompok yang Melihat Iklan dan Tidak Melihat Iklan dengan Moderasi Brand Awareness Terhadap Niat Beli (Studi Pada Commuter Line). Journal of Business Studies, 1(2).

Littlejohn, S. W. \& Foss, K. A. (2011). Teori Komunikasi (9th ed.) (M. Y. Hamdan, Trans.). Salemba Humanika. (Original work published ca. 2007).

Narsullah, R. (2015). Media Sosial: Perspektif Komunikasi, Budaya, dan Sosioteknologi. Simbiosa Rekatama Media.

Prayogo, C. (2018, October 23). Bahu-Membahu Mitigasi Perubahan Iklim. WartaEkonomi.co.id. https://www.wartaekonomi.co.id/read200369/membahu-mitigasi-perubahan-iklim.html on June 12, 2021.

PulihBersama. [@pulih.bersama]. (2021, April 15). Jangan biarkan Ibu Pertiwi menangis karena kerusakan yang disebabkan oleh tangan manusia! Budayakan diskusi dan tegaskan bahwa "Bangkitlah Bumi. [Picture]. Instagram. https://www.instagram.com/p/CNrtg-vn4LV/

PulihBersama. [@pulih.bersama]. (2021, April 15). Kami mahasiswa/i Ilmu Komunikasi Universitas Al Azhar Indonesia yang berpartisipasi pada ORGANIK KOMIK 2021 dengan bangga mempersembahkan Pulih Bersama. Pulih. [Picture]. Instagram. https://www.instagram.com/p/CNrt6FAH2n_/

PulihBersama. [@pulih.bersama]. (2021, April 15). Masyarakat nusantara dengan kearifan lokalnya sudah mampu berpikir serta mewujudkan keberlanjutan dan kelestarian lingkungannya. Mari bantu bumi bertahan yang telah. [Picture]. Instagram. https://www.instagram.com/p/CNruIZNnQH1/

PulihBersama. [@pulih.bersama]. (2021, April 17). Berbagai media menginfokan berita bencana alam yang disebabkan ulah manusia. Seakan manusia melebihi alam dan 
menjadi pengendali alam. Manusia semestinya. [Picture]. Instagram. https://www.instagram.com/p/CNxKfVkngTG/

PulihBersama. [@pulih.bersama]. (2021, April 17). Bumi di mana kita tinggal juga butuh untuk dipelajari dan dimengerti. Yuk, kita merawat bumi dengan menerapkan sistem 3 R. [Picture]. Instagram. https://www.instagram.com/p/CNxKjz8n7sE/

PulihBersama. [@pulih.bersama]. (2021, April 17). Dampak kerusakan lingkungan tidak hanya dirasakan saat ini, tetapi juga pada generasi penerus bangsa di kemudian hari. Itu mengapa menjaga. [Picture]. Instagram. https://www.instagram.com/p/CNxKa07Hefi/

Ruslan, R. (2006). Kiat dan Strategi Kampanye Public Relations (5th ed.). Raja Grafindo Persada

SDG 2030 Indonesia. (n.d.). Home. SDG 2030 Indonesia. https://www.sdg2030indonesia.org/ on June, 132021.

Sugiyono. (2009). Metode Penelitian Kuantitatif, Kualitatif dan R\&D. Alfabeta.

UGM.ac.id. (2020). Pentingnya Mitigasi dan Adaptasi terhadap Perubahan Iklim. Accessed from https://ugrg.ft.ugm.ac.id/perspektif/pentingnya-mitigasi-dan-adaptasiterhadap-perubahan-iklim/ on June, 122021.

Valentini, C. \& Kruckeberg, D. (2011). New and Social Media: The Meaning and The Use of Communication Technologies in Public Relations. Center for Global Public Relations Research Conference 2011.

Venus, A. (2012). Manajemen Kampanye: Panduan Teoretis dan Praktis dalam Mengefektifkan Kampanye Komunikasi. Simbiosa Rekatama Media.

Wicaksono, K. C. B. (2013). Mengukur Efektivitas Social Media Bagi Perusahaan. BINUS BUSINESS REVIEW, 4(3), 551-564. https://doi.org/10.21512/bbr.v4i1.1419

Winata, D. K. (2018, July 27). Masyarakat Harus Adaptif Hadapi Perubahan Iklim. mediaindonesia.com. https://mediaindonesia.com/humaniora/174719/masyarakat-harus-adaptifhadapi-perubahan-iklim 